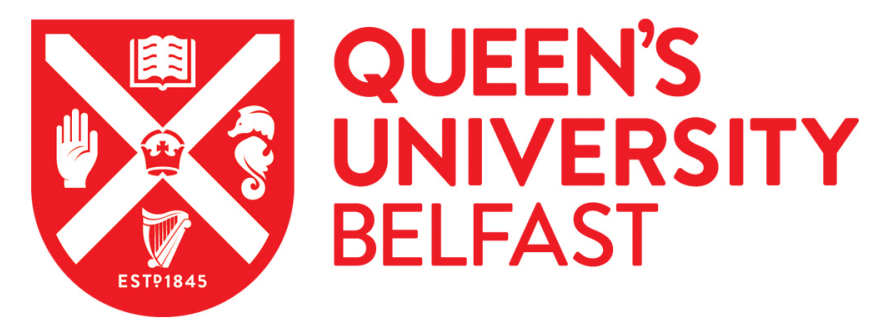

\title{
Solubility of carbon dioxide and ethane in three ionic liquids based on the bis\{(trifluoromethyl)sulfonyl\}imide anion
}

Hong, G., Jacquemin, J., Deetlefs, M., Hardacre, C., Husson, P., \& Gomes, M. F. C. (2007). Solubility of carbon dioxide and ethane in three ionic liquids based on the bis\{(trifluoromethyl)sulfonyl\}imide anion. Fluid Phase Equilibria, 257(1), 27-34. https://doi.org/10.1016/j.fluid.2007.05.002

\section{Published in:}

Fluid Phase Equilibria

Document Version:

Early version, also known as pre-print

Queen's University Belfast - Research Portal:

Link to publication record in Queen's University Belfast Research Portal

\section{General rights}

Copyright for the publications made accessible via the Queen's University Belfast Research Portal is retained by the author(s) and / or other copyright owners and it is a condition of accessing these publications that users recognise and abide by the legal requirements associated with these rights.

Take down policy

The Research Portal is Queen's institutional repository that provides access to Queen's research output. Every effort has been made to ensure that content in the Research Portal does not infringe any person's rights, or applicable UK laws. If you discover content in the Research Portal that you believe breaches copyright or violates any law, please contact openaccess@qub.ac.uk. 


\title{
Solubility of carbon dioxide and ethane in three ionic liquids based on the bis $\{$ (trifluoromethyl)sulfonyl $\}$ imide anion
}

\author{
G. Hong ${ }^{\text {a }}$, J. Jacquemin ${ }^{\mathrm{a}}$, M. Deetlefs ${ }^{\mathrm{b}}$, C. Hardacre ${ }^{\mathrm{b}}$, P. Husson ${ }^{\mathrm{a}, *}$, M.F. Costa Gomes ${ }^{\mathrm{a}}$ \\ ${ }^{a}$ Laboratoire de Thermodynamique des Solutions et des Polymères, UMR 6003 CNRS/Université Blaise Pascal, Clermont-Ferrand, \\ 24 Avenue des Landais, 63177 Aubière Cedex, France \\ ${ }^{\mathrm{b}}$ QUILL Research Center, School of Chemistry and Chemical Engineering, Queen's University of Belfast, United Kingdom
}

Received 15 February 2007; received in revised form 3 May 2007; accepted 3 May 2007

Available online 10 May 2007

\begin{abstract}
The objective of this work was to study the influence of changing the cation of the ionic liquid (IL) on gas solubility. For this purpose, the lowpressure solubility of carbon dioxide and of ethane in three ILs based on the bis $\{$ (trifluoromethyl)sulfonyl $\}$ imide anion $\left(\left[\mathrm{NTf}_{2}\right]^{-}\right)$was determined experimentally. Solubility data is reported for 1-ethyl-3-methylimidazolium $\left(\left[\mathrm{C}_{1} \mathrm{C}_{2} \mathrm{Im}\right]^{+}\right), 1$-butyl-1-methylpyrrolidinium $\left(\left[\mathrm{C}_{1} \mathrm{C}_{4} \text { pyrr }\right]^{+}\right)$and propylcholinium $\left(\left[\mathrm{N}_{1132-\mathrm{OH}}\right]^{+}\right)$bis $\{$(trifluoromethyl)sulfonyl $\}$imide ILs between 300 and $345 \mathrm{~K}$. These data are precise to within $\pm 1 \%$ and accurate to within $\pm 5 \%$. In these ILs, carbon dioxide (mole fraction solubility between 1 and $3 \times 10^{-2}$, molarity between 0.03 and $0.1 \mathrm{~mol} \mathrm{~L}^{-1}$ ) is one order of magnitude more soluble than ethane. The effect of changing the cation is small but significant. Changing the cation has a similar effect on both gases even if the differences are more pronounced in the case of ethane with the order of solubility $\left[\mathrm{C}_{1} \mathrm{C}_{4}\right.$ pyrr $]\left[\mathrm{NTf}_{2}\right]>\left[\mathrm{C}_{1} \mathrm{C}_{2} \operatorname{Im}\right]\left[\mathrm{NTf}_{2}\right]>\left[\mathrm{N}_{1132-\mathrm{OH}}\right]\left[\mathrm{NTf} \mathrm{f}_{2}\right]$. For all the systems, the solubility decreases with temperature corresponding to exothermic processes of solvation and negative enthalpies and entropies of solvation were calculated. The properties of solvation of the two gases in $\left[\mathrm{C}_{1} \mathrm{C}_{4}\right.$ pyrr $]\left[\mathrm{NTf}_{2}\right]$ do not vary significantly with temperature while important variations are depicted for both gases in $\left[\mathrm{C}_{1} \mathrm{C}_{2} \operatorname{Im}\right]\left[\mathrm{NTf}_{2}\right]$.
\end{abstract}

(c) 2007 Elsevier B.V. All rights reserved.

Keywords: Solubility; Carbon dioxide; Ethane; Ionic liquids; $\left[\mathrm{C}_{1} \mathrm{C}_{2} \mathrm{Im}\right]\left[\mathrm{NTf}_{2}\right] ;\left[\mathrm{C}_{1} \mathrm{C}_{4}\right.$ pyrro] $\left[\mathrm{NTf}_{2}\right] ;\left[\mathrm{N}_{1132-\mathrm{OH}}\right]\left[\mathrm{NTf}_{2}\right]$

\section{Introduction}

The aim of this work is to contribute to the study of the interactions between ionic liquids (ILs) containing the anion bis $\{$ (trifluoromethyl)sulfonyl $\}$ imide $\left(\left[\mathrm{NTf}_{2}\right]^{-}\right)$and two gaseous solutes, carbon dioxide and ethane through the experimental determination of gas solubility. Gas solubilities were measured as a function of temperature and at pressures close to atmospheric, using an isochoric saturation method. The data obtained provides important information for the characterization of solute-solvent interactions and so contribute to understand the mechanisms of dissolution. From a practical point of view, gas solubility can be useful in the calculation of (vapour + liquid) equilibria and thus pertinent to the development of new reaction and separation processes.

\footnotetext{
* Corresponding author. Tel.: +33 473407193; fax: +33 473405328.

E-mail address: pascale.husson@ univ-bpclermont.fr (P. Husson).
}

Our research group has previously studied the solubility of a selection of gases in two ILs namely 1-butyl-3-methylimidazolium tetrafluoroborate $\left[\mathrm{C}_{1} \mathrm{C}_{4} \mathrm{Im}\right]\left[\mathrm{BF}_{4}\right]$ [1] and 1-butyl3-methylimidazolium hexafluorophosphate $\left[\mathrm{C}_{1} \mathrm{C}_{4} \mathrm{Im}\right]\left[\mathrm{PF}_{6}\right]$ [2] as a function of temperature from 303 to $343 \mathrm{~K}$. In these two liquids, carbon dioxide was found to be the most soluble of the gases investigated, followed by ethane and methane. Other solutes including oxygen, argon, nitrogen, hydrogen and carbon monoxide showed much lower solubility. We have also studied the influence of changing the anion in 1-butyl-3-methylimidazolium-based ILs on the solubility of gaseous solutes [3]. It was observed that the gas solubilities in $\left[\mathrm{C}_{1} \mathrm{C}_{4} \mathrm{Im}\right]\left[\mathrm{BF}_{4}\right]$ and $\left[\mathrm{C}_{1} \mathrm{C}_{4} \mathrm{Im}\right]\left[\mathrm{PF}_{6}\right]$ are significantly lower than those in $\left[\mathrm{C}_{1} \mathrm{C}_{4} \operatorname{Im}\right]\left[\mathrm{NTf}_{2}\right]$.

The influence of changing the cation on the solubility of gases has also been previously investigated [4] through the study of carbon dioxide and hydrogen in three ILs composed of $\left[\mathrm{NTf}_{2}\right]^{-}$with either an imidazolium cation (1-ethyl-3-methylimidazolium, $\left[\mathrm{C}_{1} \mathrm{C}_{2} \mathrm{Im}\right]^{+}$and $\left[\mathrm{C}_{1} \mathrm{C}_{4} \mathrm{Im}\right]^{+}$) or an ammonium 
(a)

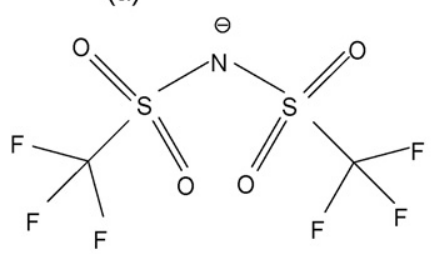

(c)

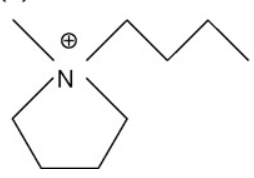

(b)

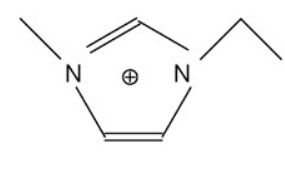

(d)

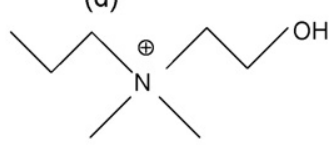

Fig. 1. Structural formula of the three ILs investigated in this work. (a) bis $\{$ (trifluoromethyl)sulfonyl $\}$ imide anion; (b) 1-ethyl-3-methylimidazolium cation; (c) 1-butyl-1-methylpyrrolidinium cation; and (d) propylcholinium cation.

cation (butyl-trimethylammonium, $\left[\mathrm{N}_{4111}\right]^{+}$). In contrast with variation with the IL anion, the cation influence was found to be much smaller. Both gases studied were found more soluble in the ammonium-based IL studied than in the two imidazoliumbased ILs. Moreover, a slight increase of the solubility was systematically observed when increasing the chain length on the imidazolium cation.

Herein, it is our aim to continue the study of the influence of changing the cation of the IL on the solubility of gaseous solutes. We have chosen three ILs based on the $\left[\mathrm{NTf}_{2}\right]^{-}$anion combined with either an aromatic ring $\left(\left[\mathrm{C}_{1} \mathrm{C}_{2} \mathrm{Im}\right]^{+}\right)$or a cycle (1-butyl-1-methylpyrrolidinium, $\left[\mathrm{C}_{1} \mathrm{C}_{4} \text { pyrr }\right]^{+}$) and hydroxyl functionalised acyclic (propylcholinium $\left[\mathrm{N}_{1132-\mathrm{OH}}\right]^{+}$) tetraalkylammonium cation as shown in Fig. 1.

The solubility of carbon dioxide in a variety of ILs has been determined at low pressures [1-10] and high pressures (up to $73 \mathrm{MPa}$ ) [11-24]. In particular, the system (carbon dioxide $\left.+\left[\mathrm{C}_{1} \mathrm{C}_{2} \mathrm{Im}\right]\left[\mathrm{NTf}_{2}\right]\right)$, also investigated in this work, was studied by several authors [7-10,14,17]. Camper et al. [7,8,10] have determined the solubility of carbon dioxide experimentally in this IL from 303 to $343 \mathrm{~K}$ and at low pressures by isochoric $p V T$ measurements. The reported Henry's law constants (4.0 MPa at $303 \mathrm{~K}$ and $7.7 \mathrm{MPa}$ at $343 \mathrm{~K}$ ) increase when increasing temperature corresponding to a decrease of the solubility with temperature. Morgan et al. [9], whose main focus was to determine the experimental diffusivity of carbon dioxide in a variety of ILs, also measured the solubility of this gas by passing it through a supported IL film and measuring the gas pressure after the membrane at equilibrium. At $313 \mathrm{~K}$, the solubility of carbon dioxide in $\left[\mathrm{C}_{1} \mathrm{C}_{2} \mathrm{Im}\right]\left[\mathrm{NTf}_{2}\right]$ was found to be $0.1 \mathrm{~mol} \mathrm{~L}^{-1} \mathrm{~atm}^{-1}$ which corresponds to a Henry's law constant of 4.1 MPa. Cadena et al. [14] used a gravimetric microbalance to determine the solubility of carbon dioxide in $\left[\mathrm{C}_{1} \mathrm{C}_{2} \mathrm{Im}\right]\left[\mathrm{NTf}_{2}\right]$ between 283 and $323 \mathrm{~K}$ and at pressures up to $1.4 \mathrm{MPa}$. Their measured Henry's law constants increase with temperature and vary from 2.53 to $5.15 \mathrm{MPa}$. Finally, Kim et al. [17] have measured the solubility of carbon dioxide in $\left[\mathrm{C}_{1} \mathrm{C}_{2} \mathrm{Im}\right]\left[\mathrm{NTf}_{2}\right]$ at $298.15 \mathrm{~K}$ and up to $1 \mathrm{MPa}$ with a method similar to that of Cadena et al. [14]. Therein, the Henry's law constant calculated by extrapolating their data at atmospheric pressure was nearly $30 \%$ higher than that reported by Cadena et al. [14] at the same temperature. To the best of our knowledge, only Anthony et al. [12] have measured the solubility of carbon dioxide in $\left[\mathrm{C}_{1} \mathrm{C}_{4}\right.$ pyrr] $\left[\mathrm{NTf}_{2}\right]$ and reported Henry's law constants at 283,298 and $323 \mathrm{~K}$ of $3.02,3.86$ and $5.61 \mathrm{MPa}$, respectively.

In comparison, the solubility of ethane in ILs has been far less studied than the solubility of carbon dioxide $[1,2,8,10,11]$. Camper et al. $[8,10]$ have studied the system ethane $+\left[\mathrm{C}_{1} \mathrm{C}_{2} \mathrm{Im}\right]\left[\mathrm{NTf}_{2}\right]$ which is also reported herein. Henry's law constants of $10.7 \mathrm{MPa}$ at $303 \mathrm{~K}$ and of $16.8 \mathrm{MPa}$ at $313 \mathrm{~K}$ were found with the solubility decreasing with increasing temperature.

The solubility of carbon dioxide and ethane has been investigated in a wide range of imidazolium-based ILs including $\left[\mathrm{C}_{1} \mathrm{C}_{2} \mathrm{Im}\right]\left[\mathrm{NTf}_{2}\right] \quad[8,10], \quad\left[\mathrm{C}_{1} \mathrm{C}_{4} \mathrm{Im}\right]\left[\mathrm{NTf}_{2}\right] \quad$ [22], $\left[\mathrm{C}_{1} \mathrm{C}_{4} \mathrm{Im}\right]\left[\mathrm{BF}_{4}\right][1,10],\left[\mathrm{C}_{1} \mathrm{C}_{4} \mathrm{Im}\right]\left[\mathrm{PF}_{6}\right][2,10,11]$, 1-ethyl-3methylimidazolium dicyanamide $\left(\left[\mathrm{C}_{1} \mathrm{C}_{2} \mathrm{Im}\right][\mathrm{dca}]\right)[10]$ and 1-ethyl-3-methylimidazolium triflate $\left(\left[\mathrm{C}_{1} \mathrm{C}_{2} \mathrm{Im}\right][\mathrm{OTf}]\right)[10]$. In all these ILs, carbon dioxide exhibits a higher solubility than ethane.

In general, changing the anion of the IL has a larger impact on the gas solubility than modifying the cation $[3,6,12,14,15]$. The presence of the $\left[\mathrm{NTf}_{2}\right]^{-}$anion systematically increases the solubility of carbon dioxide $[3,6,12,14]$ this anion showing a larger affinity for this solute regardless of whether the liquid is based on the imidazolium, pyrrolidinium or ammonium cations [12]. The effect of changing the cation of the IL on the solubility of gases is less significant [12,15]. A slight increase of the solubility of carbon dioxide when increasing the alkyl side chain length in the imidazolium cation was observed $[6,15,23]$. In addition, Anthony et al. [12] compared the solubility of carbon dioxide in three ILs containing the anion $\left[\mathrm{NTf}_{2}\right]^{-}$and either an imidazolium, an ammonium or a pyrrolidinium cation. Replacing the imidazolium cation with either the tetraalkylammoinum-based cations resulted in a decrease in the solubility of carbon dioxide of between 15 and $30 \%$. Interestingly, Baltus et al. [6] have observed, using a quartz crystal microbalance, a significantly greater carbon dioxide solubility in imidazolium-based ILs having fluorine-substituted cation as compared with the corresponding IL with a nonfluorinated cation. In this case the Henry's constant differs by a factor of seven between $\left[\mathrm{C}_{1} \mathrm{C}_{8} \mathrm{Im}\right]\left[\mathrm{NTf}_{2}\right]$ and the corresponding fluorine-substituted IL $\left.\left[\mathrm{C}_{1}\left(\mathrm{C}_{8} \mathrm{~F}_{3}\right) \mathrm{Im}\right]\left[\mathrm{NTf}_{2}\right]\right)$. This observation is compatible with the known affinity of carbon dioxide by fluorinated solvents [37].

In the present work, the selected ILs with the exception of $\left[\mathrm{C}_{1} \mathrm{C}_{2} \mathrm{Im}\right]\left[\mathrm{NTf}_{2}\right]$ are not commonly studied. The solubility of carbon dioxide and ethane, was precisely determined as a function of temperature from 303 to $343 \mathrm{~K}$ and at pressures close to atmospheric using a high precision isochoric saturation method. The knowledge of the variation with temperature of the solubility allows the calculation of the thermodynamic properties of solvation. 


\section{Experimental}

The IL $\left[\mathrm{C}_{1} \mathrm{C}_{2} \mathrm{Im}\right]\left[\mathrm{NTf}_{2}\right]$ was prepared at the QUILL research center at Belfast, using the standard synthesis procedures described by Bonhôte et al. [25]. The bromide content of this IL sample was determined using ion chromatography (IC) [26] and was found to be below the $5 \mathrm{ppm}$ detection limit. The water content was determined before and after the solubility measurements by volumetric Karl-Fisher titration using a Mettler Toledo DL31 titrator. A reference value of $45 \mathrm{ppm}$ (w/w) of water was obtained after drying the liquid in vacuo at $303 \mathrm{~K}$ for $8 \mathrm{~h}$. The bromide content of the $\left[\mathrm{C}_{1} \mathrm{C}_{4}\right.$ pyrr $]\left[\mathrm{NTf}_{2}\right]$ and chloride content of the $\left[\mathrm{N}_{1132-\mathrm{OH}}\right]\left[\mathrm{NTf}_{2}\right]$ samples were also determined using IC and were found to lay below the detection limit of $5 \mathrm{ppm}$. The water contents of these samples, determined as previously were respectively of 70 and $45 \mathrm{ppm}(\mathrm{w} / \mathrm{w})$ after the same treatment as previously.

The carbon dioxide ( $>0.99995 \mathrm{~mol}$ fraction) and ethane ( $>0.995$ mol fraction) were purchased from AGA/Linde Gaz and were used as received.

The experimental apparatus used for the low-pressure gas solubility measurements is based on an isochoric saturation technique that has been described in previous publications [1-4]. In this technique, a known quantity of gaseous solute is placed in contact with a precisely determined quantity of degassed solvent at constant temperature inside an accurately known volume. When thermodynamic equilibrium is attained, the pressure above the liquid solution is constant and directly related to the solubility of the gas in the liquid.

The quantity of IL introduced in the equilibration cell is determined gravimetrically, $V_{\text {liq }}$ being calculated from the density of the IL. The amount of solute present in the liquid solution, $n_{2}^{\text {liq }}$, is calculated by the difference between the $p V T$ measured when the gas is initially introduced in a calibrated bulb with volume $V_{\mathrm{GB}}$ and then after thermodynamic equilibrium is reached (it is assumed that the volume of the saturated solution is the same of that of the pure IL):

$n_{2}^{\operatorname{liq}}=\frac{p_{\text {ini }} V_{\mathrm{GB}}}{\left[Z_{2}\left(p_{\mathrm{ini}}, T_{\mathrm{ini}}\right) R T_{\mathrm{ini}}\right]}-\frac{p_{\mathrm{eq}}\left(V_{\mathrm{tot}}-V_{\mathrm{liq}}\right)}{\left[Z_{2}\left(p_{\mathrm{eq}}, T_{\mathrm{eq}}\right) R T_{\mathrm{eq}}\right]}$

where $p_{\text {ini }}$ and $T_{\text {ini }}$ are the pressure and temperature in the first $p V T$ determination and $p_{\mathrm{eq}}$ and $T_{\mathrm{eq}}$ the pressure and temperature at the equilibrium. $V_{\text {tot }}$ is the total volume of the equilibration cell and $Z_{2}$ is the compressibility factor for the pure gas. The solubility is then expressed in mole fraction:

$x_{2}=\frac{n_{2}^{\text {liq }}}{n_{1}^{\text {liq }}+n_{2}^{\text {liq }}}$

or as Henry's law constant:

$K_{\mathrm{H}}=\lim _{x_{2} \rightarrow 0} \frac{f_{2}\left(p, T, x_{2}\right)}{x_{2}} \cong \frac{\phi_{2}\left(p_{\mathrm{eq}}, T_{\mathrm{eq}}\right) p_{\mathrm{eq}}}{x_{2}}$

where $f_{2}$ is the fugacity of the solute and $\phi_{2}$ its fugacity coefficient calculated in the usual way [36]. In all cases, the subscript 2 denotes the solute and subscript 1 denotes the solvent.
The Henry' law constants can be exactly converted to the Gibbs energy of solvation, $\Delta_{\text {solv }} G^{\infty}$, corresponding to the change in Gibbs energy when the solute is transferred, at constant temperature, from the pure perfect gas state at the standard pressure to the standard state of infinite dilution of the solute in the solvent:

$\Delta_{\text {solv }} G^{\infty}=R T \ln \left(\frac{K_{\mathrm{H}}}{p^{0}}\right)$

where $p^{0}$ is the standard state pressure. From the temperature variation of $K_{\mathrm{H}}$, other thermodynamic properties of solvation can be calculated, which in the case of gaseous solutes at low pressures, can be approximated to the thermodynamic properties of solution [35]. The differences in enthalpy and entropy between the two standard states referred above $\left(\Delta_{\text {solv }} H^{\infty}\right.$ and $\Delta_{\text {solv }} S^{\infty}$, respectively) can be obtained by taking the corresponding partial derivatives of the Gibbs energy with respect to temperature:

$\Delta_{\text {solv }} H^{\infty}=-R T^{2} \frac{\partial}{\partial T}\left[\ln \left(\frac{K_{\mathrm{H}}}{p^{0}}\right)\right]$,

$\Delta_{\text {solv }} S^{\infty}=-R T \frac{\partial}{\partial T}\left[\ln \left(\frac{K_{\mathrm{H}}}{p^{0}}\right)\right]-R \ln \left(\frac{K_{\mathrm{H}}}{p^{0}}\right)$

The densities of the three ILs investigated, necessary for the calculation of $V_{\text {liq }}$ in Eq. (1), were determined in house from 293 to $343 \mathrm{~K}$, with an overall precision of $0.01 \%$ using an Anton Paar densitometer (model DMA 512 P) [29].

\section{Results and discussion}

For each system, multiple experimental data points were obtained between 293 and $343 \mathrm{~K}$ in steps of approximately $10 \mathrm{~K}$. The experimental solubilities of carbon dioxide and ethane in $\left[\mathrm{C}_{1} \mathrm{C}_{2} \mathrm{Im}\right]\left[\mathrm{NTf}_{2}\right],\left[\mathrm{C}_{1} \mathrm{C}_{4}\right.$ pyrr $]\left[\mathrm{NTf}_{2}\right]$ and $\left[\mathrm{N}_{1132-\mathrm{OH}}\right]\left[\mathrm{NTf}_{2}\right]$ are reported in Table 1 . The solubility results are expressed as mole fractions of solute and as Henry's law constants. The mole fraction solubilities, at the reference pressure of $0.1 \mathrm{MPa}$, are calculated from the experimental data on $K_{\mathrm{H}}$ (at slightly different total pressures) assuming a partial pressure of the gaseous solute equal to $0.1 \mathrm{MPa}$. The relative atomic masses used are those recommended by IUPAC [27] and the values of the second virial coefficients, necessary for the calculation of the compressibility factor, were taken from the compilation by Dymond and Smith [28].

The density values were fitted to linear functions of the temperature (the average absolute deviation of the fit is $0.005 \%$ ):

$\rho_{\left[\mathrm{C}_{1} \mathrm{C}_{2} \operatorname{Im}\right]\left[\mathrm{NTF}_{2}\right]}\left(\mathrm{kg} \mathrm{m}^{-3}\right)=1817.0-1.0009(T / \mathrm{K})$

$\rho_{\left[\mathrm{C}_{1} \mathrm{C}_{4} \text { pyrro }\right]\left[\mathrm{NTf}_{2}\right]}\left(\mathrm{kg} \mathrm{m}^{-3}\right)=1658.9-0.8872(T / \mathrm{K})$

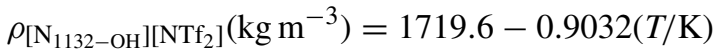

The measured density of $\left[\mathrm{C}_{1} \mathrm{C}_{2} \mathrm{Im}\right]\left[\mathrm{NTf}_{2}\right]$ can be compared with previously published data [30-33]. The largest deviation found is of $0.2 \%$ between the present data and those of Refs. $[32,33]$. The density of $\left[\mathrm{C}_{1} \mathrm{C}_{4}\right.$ pyrr $]\left[\mathrm{NTf}_{2}\right]$ was measured by Anthony et al. [12] and shows a deviation from the present data 
Table 1

Experimental values of gas solubilities in the three ILs investigated expressed both as Henry's law constants, $K_{\mathrm{H}}$ and as mole fraction, $x_{2}$, corrected for a partial pressure of solute of $0.1 \mathrm{MPa}$

\begin{tabular}{|c|c|c|c|c|}
\hline$T(\mathrm{~K})$ & $p\left(\times 10^{2} \mathrm{~Pa}\right)$ & $K_{\mathrm{H}}\left(\times 10^{5} \mathrm{~Pa}\right)$ & $x_{2}\left(\times 10^{-3}\right)$ & Deviation (\%) \\
\hline \multicolumn{5}{|c|}{$\left[\mathrm{C}_{1} \mathrm{C}_{2} \mathrm{Im}\right]\left[\mathrm{NTf}_{2}\right]+\mathrm{CO}_{2}$} \\
\hline 303.63 & 479.17 & 38.08 & 26.14 & -0.3 \\
\hline 303.87 & 464.06 & 38.61 & 25.78 & +0.6 \\
\hline 313.87 & 495.92 & 45.85 & 21.72 & -0.1 \\
\hline 313.92 & 492.93 & 46.22 & 21.55 & +0.6 \\
\hline 313.95 & 500.63 & 45.43 & 21.92 & -1.2 \\
\hline 323.96 & 519.63 & 54.15 & 18.40 & -0.1 \\
\hline 323.98 & 520.40 & 54.64 & 18.23 & +0.7 \\
\hline 324.05 & 433.03 & 53.92 & 18.48 & -0.7 \\
\hline 324.12 & 521.60 & 54.47 & 18.29 & +0.2 \\
\hline 334.07 & 542.17 & 62.93 & 15.84 & -0.5 \\
\hline 334.10 & 546.15 & 63.43 & 15.71 & +0.3 \\
\hline 334.16 & 448.41 & 63.90 & 15.60 & +0.9 \\
\hline 343.99 & 563.75 & 72.51 & 13.75 & -0.3 \\
\hline 344.23 & 570.97 & 72.90 & 13.68 & -0.1 \\
\hline \multicolumn{5}{|c|}{$\left[\mathrm{C}_{1} \mathrm{C}_{2} \mathrm{Im}\right]\left[\mathrm{NTf}_{2}\right]+\mathrm{C}_{2} \mathrm{H}_{6}$} \\
\hline 304.14 & 442.33 & 150.5 & 6.599 & -0.3 \\
\hline 304.15 & 442.25 & 149.6 & 6.639 & +0.3 \\
\hline 314.25 & 456.31 & 171.5 & 5.793 & -0.2 \\
\hline 314.29 & 456.29 & 170.7 & 5.821 & +0.3 \\
\hline 324.43 & 470.27 & 196.5 & 5.060 & +0.1 \\
\hline 324.44 & 470.31 & 196.9 & 5.049 & -0.1 \\
\hline 334.58 & 484.23 & 229.4 & 4.337 & -1.1 \\
\hline 334.63 & 484.07 & 224.8 & 4.425 & +0.9 \\
\hline 344.70 & 497.70 & 261.8 & 3.802 & +0.1 \\
\hline \multicolumn{5}{|c|}{$\left[\mathrm{C}_{1} \mathrm{C}_{4}\right.$ pyrr $]\left[\mathrm{NTf}_{2}\right]+\mathrm{CO}_{2}$} \\
\hline 303.78 & 486.78 & 36.65 & 27.15 & +0.0 \\
\hline 313.80 & 509.47 & 43.63 & 22.82 & +0.7 \\
\hline 313.85 & 505.34 & 42.99 & 23.16 & -0.9 \\
\hline 323.94 & 531.34 & 51.21 & 19.45 & +0.8 \\
\hline 323.96 & 526.15 & 50.64 & 19.67 & -0.3 \\
\hline 334.04 & 545.97 & 58.47 & 17.04 & -0.7 \\
\hline 334.04 & 552.17 & 59.08 & 16.87 & +0.4 \\
\hline 334.10 & 546.17 & 58.67 & 16.99 & -0.4 \\
\hline 344.04 & 565.53 & 67.57 & 14.75 & +0.1 \\
\hline 344.05 & 565.45 & 67.39 & 14.79 & -0.2 \\
\hline 344.15 & 572.64 & 67.81 & 14.70 & +0.3 \\
\hline \multicolumn{5}{|c|}{$\left[\mathrm{C}_{1} \mathrm{C}_{4} \mathrm{pyrr}\right]\left[\mathrm{NTf}_{2}\right]+\mathrm{C}_{2} \mathrm{H}_{6}$} \\
\hline 304.24 & 388.75 & 105.2 & 9.441 & +0.2 \\
\hline 314.25 & 401.63 & 120.2 & 8.269 & -0.2 \\
\hline 324.40 & 414.36 & 136.2 & 7.300 & -0.7 \\
\hline 334.51 & 427.15 & 156.9 & 6.340 & +1.1 \\
\hline 344.69 & 439.26 & 173.7 & 5.730 & -0.5 \\
\hline \multicolumn{5}{|c|}{$\left[\mathrm{N}_{1132-\mathrm{OH}}\right]\left[\mathrm{NTf}_{2}\right]+\mathrm{CO}_{2}$} \\
\hline 304.16 & 467.00 & 41.75 & 23.84 & +0.2 \\
\hline 314.26 & 487.52 & 50.15 & 19.85 & +0.1 \\
\hline 324.46 & 507.04 & 59.44 & 16.76 & -0.5 \\
\hline 324.47 & 507.04 & 59.42 & 16.77 & -0.6 \\
\hline 334.61 & 526.21 & 70.83 & 14.07 & +0.7 \\
\hline 334.68 & 526.33 & 70.91 & 14.05 & +0.7 \\
\hline 344.84 & 543.86 & 81.66 & 12.21 & -0.6 \\
\hline \multicolumn{5}{|c|}{$\left[\mathrm{N}_{1132-\mathrm{OH}}\right]\left[\mathrm{NTf}_{2}\right]+\mathrm{C}_{2} \mathrm{H}_{6}$} \\
\hline 304.15 & 436.37 & 159.9 & 6.209 & -1.2 \\
\hline 304.22 & 436.77 & 164.2 & 6.047 & +1.4 \\
\hline 314.21 & 450.39 & 189.3 & 5.248 & +1.6 \\
\hline 314.28 & 450.10 & 183.1 & 5.427 & -1.9 \\
\hline 324.35 & 463.70 & 211.8 & 4.694 & -1.0 \\
\hline 324.39 & 463.91 & 215.4 & 4.617 & +0.6 \\
\hline 334.36 & 477.05 & 245.2 & 4.057 & +0.3 \\
\hline 334.59 & 477.37 & 246.8 & 4.031 & +0.6 \\
\hline 344.74 & 490.48 & 278.4 & 3.575 & -0.4 \\
\hline
\end{tabular}

$p$ is the experimental equilibrium pressure and the per cent deviation is relative to the correlations of the data reported in Table 2.
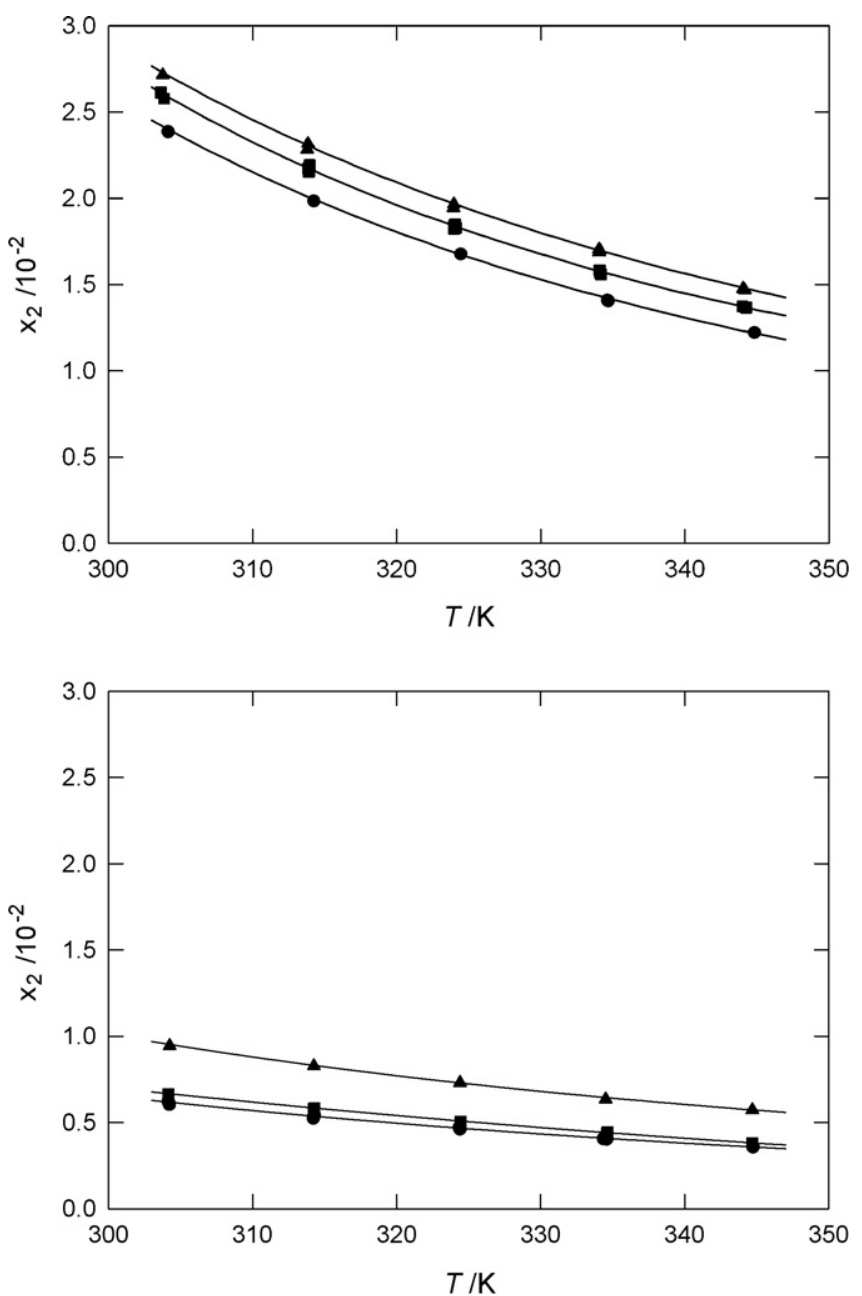

Fig. 2. Mole fraction gas solubilities of carbon dioxide (upper plot) and of ethane (lower plot) in the three ILs at $0.1 \mathrm{MPa}$ partial pressure as a function of temperature: $(\mathbf{\square})\left[\mathrm{C}_{1} \mathrm{C}_{2} \mathrm{Im}\right]\left[\mathrm{NTf}_{2}\right] ;(\boldsymbol{\Delta})\left[\mathrm{C}_{1} \mathrm{C}_{4}\right.$ pyrr $]\left[\mathrm{NTf}_{2}\right]$; and $(\boldsymbol{O})\left[\mathrm{N}_{1132-\mathrm{OH}}\right]\left[\mathrm{NTf}_{2}\right]$. The curves represent Eq. (9) with parameters shown in Table 2.

of $0.02 \%$ at $293 \mathrm{~K}$ and of $0.3 \%$ at $323 \mathrm{~K}$. To our knowledge, no density data were previously published for $\left[\mathrm{N}_{1132-\mathrm{OH}}\right]\left[\mathrm{NTf}_{2}\right]$.

To get representative values of the solubility, the Henry's law constants presented in Table 1 were correlated as a function of temperature by an empirical equation of the type:

$\ln \left[K_{\mathrm{H}}(T) / 10^{5} \mathrm{~Pa}\right]=\sum_{i=0}^{n} A_{i}(T / \mathrm{K})^{-i}$

The coefficients $A_{i}$ obtained are listed in Table 2 together with the average absolute deviations obtained. When a sufficiently large number of independent experimental determinations are available, these deviations are a good approximation to the statistical error estimation obtained from the propagation of the experimental uncertainties in pressure, temperature and IL mass. These values can thus be regarded as an estimation of the precision of the solubility data considered in the present case as $\pm 1 \%$.

In Fig. 2 the solubility, expressed in mole fraction, for the two gases in the ILs as a function of temperature is presented. In the three ILs investigated, carbon dioxide (mole fraction sol- 
Table 2

Parameters of Eq. (9) which describes the experimental results on $K_{\mathrm{H}}$ from Table 1 along with the per cent average absolute deviation of the fit (AAD)

\begin{tabular}{lcccc}
\hline System & $A_{0}$ & $A_{1}$ & $A_{2}$ & AAD (\%) \\
\hline$\left[\mathrm{C}_{1} \mathrm{C}_{2} \mathrm{Im}\right]\left[\mathrm{NTf}_{2}\right]+\mathrm{CO}_{2}$ & +7.595 & $-6.716 \times 10^{2}$ & $-1.604 \times 10^{5}$ & 0.5 \\
{$\left[\mathrm{C}_{1} \mathrm{C}_{2} \mathrm{Im}\right]\left[\mathrm{NTf}_{2}\right]+\mathrm{C}_{2} \mathrm{H}_{6}$} & +16.22 & $-5.639 \times 10^{3}$ & $+6.780 \times 10^{5}$ & $-2.514 \times 10^{4}$ \\
{$\left[\mathrm{C}_{1} \mathrm{C}_{4}\right.$ pyrr $]\left[\mathrm{NTf}_{2}\right]+\mathrm{CO}_{2}$} & +8.579 & $-1.429 \times 10^{3}$ & $+5.279 \times 10^{4}$ & 0.4 \\
{$\left[\mathrm{C}_{1} \mathrm{C}_{4}\right.$ pyrr] $]\left[\mathrm{NTf}_{2}\right]+\mathrm{C}_{2} \mathrm{H}_{6}$} & +9.487 & $-1.644 \times 10^{3}$ & $+8.673 \times 10^{1}$ & 0.5 \\
{$\left[\mathrm{~N}_{1132-\mathrm{OH}}\right]\left[\mathrm{NTf}_{2}\right]+\mathrm{CO}_{2}$} & +9.478 & $-1.748 \times 10^{3}$ & $+2.554 \times 10^{5}$ \\
{$\left[\mathrm{~N}_{1132-\mathrm{OH}}\right]\left[\mathrm{NTf}_{2}\right]+\mathrm{C}_{2} \mathrm{H}_{6}$} & +12.16 & $-2.992 \times 10^{4}$ & 0.4 \\
\hline
\end{tabular}

ubility between 1 and $3 \times 10^{-2}$, molarity between 0.03 and $0.1 \mathrm{~mol} \mathrm{~L}^{-1}$ ) is one order of magnitude more soluble than ethane (mole fraction solubility between 4 and $10 \times 10^{-3}$, molarity between 0.01 and $0.04 \mathrm{~mol} \mathrm{~L}^{-1}$ ). This is in good agreement with the data reported by Camper et al. $[8,10]$ for the ionic liquid $\left[\mathrm{C}_{1} \mathrm{C}_{2} \mathrm{Im}\right]\left[\mathrm{NTf}_{2}\right]$ and is compatible with the values reported for other imidazolium-based ILs $[1,2,10,11]$. The higher solubility of carbon dioxide in the ILs has been explained by the importance of the solute-solvent electrostatic interactions [34].

The present results indicate that the presence of the pyrrolidinium cation increases the solubility of both gases while the
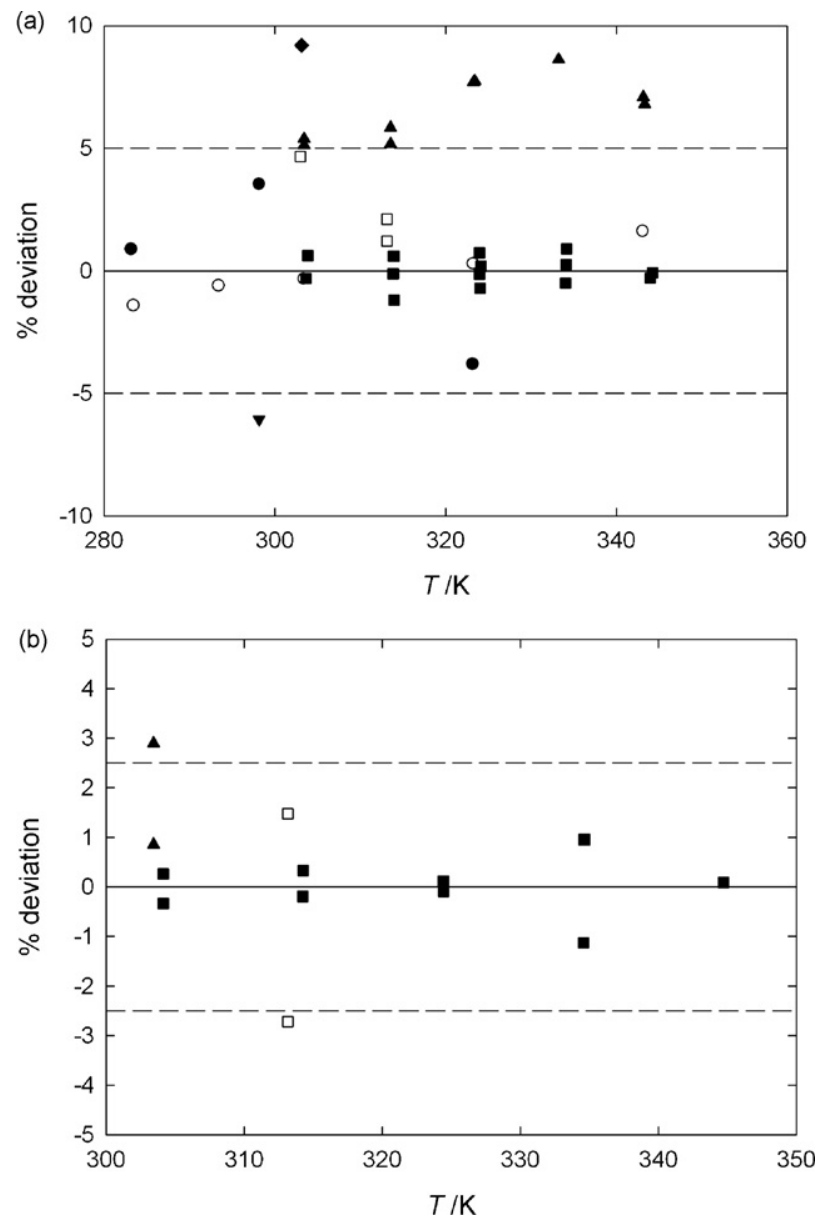

Fig. 3. Percent deviations from the literature values to the correlation of the Henry's law constants obtained in this work for carbon dioxide in $\left[\mathrm{C}_{1} \mathrm{C}_{2} \mathrm{im}\right]\left[\mathrm{Ntf}_{2}\right]$ (a) and for ethane in $\left[\mathrm{C}_{1} \mathrm{C}_{2} \mathrm{im}\right]\left[\mathrm{Ntf}_{2}\right]$ (b): (ם) this work; $(\mathrm{O})$ Jacquemin et al. [4]; ( $\square$ ) Camper et al. [7,10]; (\) Camper et al. [8]; ( $)$ Morgan et al. [9]; (৩) Cadena et al. [14]; and ( $\mathbf{\nabla})$ Kim et al. [17]. lower solubilities were measured in the ammonium-based IL containing an alcohol function. The influence of changing the cation is more significant for ethane than for carbon dioxide solubility. For example, the presence of pyrrolidinium cation increases the solubility of ethane by nearly $50 \%$ compared with the solubility in the two other ILs investigated. The carbon dioxide solubility only increases at most $21 \%$ in the presence of this cation.

Fig. 3 shows deviation plots with differences between the various literature sources and the correlation of the present data for the systems: $\left[\mathrm{C}_{1} \mathrm{C}_{2} \mathrm{Im}\right]\left[\mathrm{NTf}_{2}\right]+$ carbon dioxide and $\left[\mathrm{C}_{1} \mathrm{C}_{2} \mathrm{Im}\right]\left[\mathrm{NTf}_{2}\right]+$ ethane in order to estimate the accuracy of the data in this work. For $\left[\mathrm{C}_{1} \mathrm{C}_{2} \mathrm{Im}\right]\left[\mathrm{NTf}_{2}\right]+$ carbon dioxide (Fig. 3a), the values reported by Cadena et al. [14], by Camper et al. [7,10] and by our research group in a previous study [4] (using the same type of experimental apparatus but another sample of IL) deviate from the present work less than 5\%. Another set of data from Camper et al. [8] for the same system show a larger deviation specially at the higher temperature end. Finally, two sets of data, reported by Kim et al. [17] and by Morgan et al. [9], exhibit a difference of more than $5 \%$ from the present data. These higher deviations can be explained, in the case of Morgan et al. [9] by a $10 \%$ error claimed by the authors for their experimental solubilities. Concerning the data of Kim et al. [17], a pressure extrapolation was necessary to calculate the Henry's

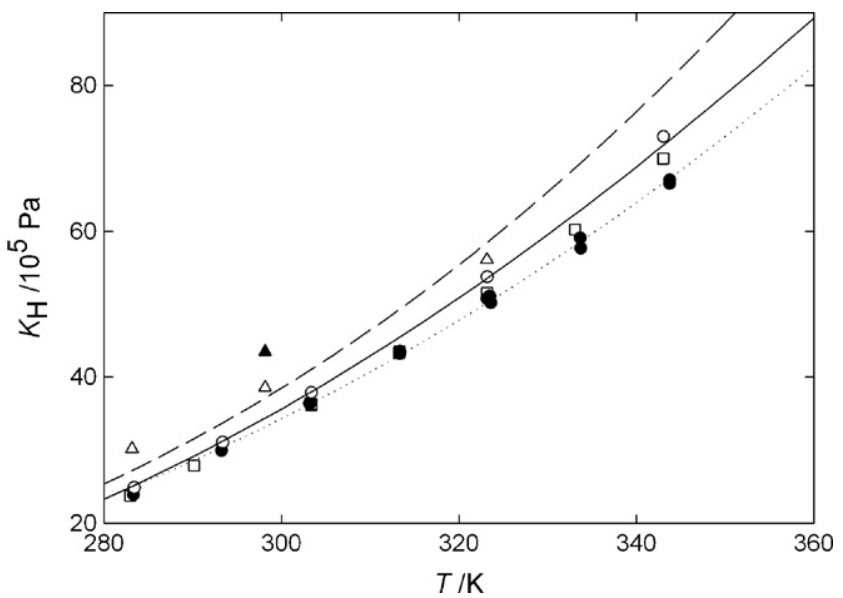

Fig. 4. Literature values of Henry's law constants as a function of temperature for carbon dioxide in $\left[\mathrm{C}_{1} \mathrm{C}_{2} \mathrm{Im}\right]\left[\mathrm{NTf}_{2}\right]$ : $(\bigcirc)$ Jacquemin et al. [4];

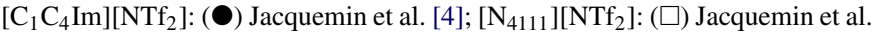
[4]; [ $\left.\mathrm{N}_{1444}\right]\left[\mathrm{NTf}_{2}\right]$ : ( $\left.\mathbf{\Lambda}\right)$ Anthony et al. [12]; and $\left[\mathrm{C}_{1} \mathrm{C}_{4}\right.$ pyrr] $\left[\mathrm{NTf}_{2}\right]$ : $(\triangle)$ Anthony et al. [12]. The curves represent Eq. (9) with parameters shown in Table 2: (一), $\left[\mathrm{C}_{1} \mathrm{C}_{2} \mathrm{Im}\right]\left[\mathrm{NTf}_{2}\right] ;(---),\left[\mathrm{N}_{1132-\mathrm{OH}}\right]\left[\mathrm{NTf}_{2}\right] ;(\cdots),\left[\mathrm{C}_{1} \mathrm{C}_{4}\right.$ pyrr $]\left[\mathrm{NTf}_{2}\right]$. 
law constants from their high-pressure measurements at $298 \mathrm{~K}$. The precision of this fit can explain the differences found in the solubilities.

Fig. $3 \mathrm{~b}$ presents the deviations between the present set of data and those previously reported for $\left[\mathrm{C}_{1} \mathrm{C}_{2} \mathrm{mim}\right]\left[\mathrm{NTf}_{2}\right]+$ ethane. This system has been investigated by Camper et al. [8,10] at 303 and $313 \mathrm{~K}$ and agree to within $4 \%$ with the present set of data.

Only Anthony et al. [12] report the solubility of $\mathrm{CO}_{2}$ in $\left[\mathrm{C}_{1} \mathrm{C}_{4}\right.$ pyrr] $\left[\mathrm{NTf}_{2}\right]$ at three temperatures from 283 to $323 \mathrm{~K}$. Their Henry's law constants, obtained by extrapolation of highpressure data, agree with the ones obtained in the present work to within $10 \%$ at $323 \mathrm{~K}$. At the lower temperatures considered by these authors, not studied in the present work, deviations up to $22 \%$ are calculated between their data and the extrapolation at lower temperatures of our solubility data. Because of these extrapolations, these values were not considered in the estimation of the accuracy of the present data.

Table 3

Thermodynamic functions of solvation for the carbon dioxide and ethane in the three ILs investigated at several discrete temperatures between 305 and $345 \mathrm{~K}$

\begin{tabular}{|c|c|c|c|}
\hline$T(\mathrm{~K})$ & $\Delta_{\mathrm{sol}} G^{\infty}\left(\mathrm{kJ} \mathrm{mol}^{-1}\right)$ & $\Delta_{\mathrm{sol}} H^{\infty}\left(\mathrm{kJ} \mathrm{mol}^{-1}\right)$ & $\Delta_{\mathrm{sol}} S^{\infty}\left(\mathrm{J} \mathrm{mol}^{-1} \mathrm{~K}^{-1}\right)$ \\
\hline \multicolumn{4}{|c|}{$\left[\mathrm{C}_{1} \mathrm{C}_{2} \mathrm{Im}\right]\left[\mathrm{NTf}_{2}\right]+\mathrm{CO}_{2}$} \\
\hline 305 & 9.308 & -14.3 & -77.5 \\
\hline 315 & 10.08 & -14.0 & -76.6 \\
\hline 325 & 10.84 & -13.8 & -75.8 \\
\hline 335 & 11.59 & -13.5 & -75.0 \\
\hline 345 & 12.34 & -13.3 & -74.3 \\
\hline \multicolumn{4}{|c|}{$\left[\mathrm{C}_{1} \mathrm{C}_{2} \mathrm{Im}\right]\left[\mathrm{NTf}_{2}\right]+\mathrm{C}_{2} \mathrm{H}_{6}$} \\
\hline 305 & 12.73 & -9.92 & -74.3 \\
\hline 315 & 13.50 & -11.1 & -78.1 \\
\hline 325 & 14.29 & -12.2 & -81.5 \\
\hline 335 & 15.12 & -13.2 & -84.6 \\
\hline 345 & 15.99 & -14.2 & -87.5 \\
\hline \multicolumn{4}{|c|}{$\left[\mathrm{C}_{1} \mathrm{C}_{4}\right.$ pyrr $]\left[\mathrm{NTf}_{2}\right]+\mathrm{CO}_{2}$} \\
\hline 305 & 9.186 & -13.3 & -73.6 \\
\hline 315 & 9.922 & -13.2 & -73.4 \\
\hline 325 & 10.66 & -13.2 & -73.3 \\
\hline 335 & 11.39 & -13.1 & -73.2 \\
\hline 345 & 12.12 & -13.1 & -73.1 \\
\hline \multicolumn{4}{|c|}{$\left[\mathrm{C}_{1} \mathrm{C}_{4}\right.$ pyrr $]\left[\mathrm{NTf}_{2}\right]+\mathrm{C}_{2} \mathrm{H}_{6}$} \\
\hline 305 & 11.83 & -10.8 & -74.2 \\
\hline 315 & 12.57 & -10.9 & -74.5 \\
\hline 325 & 13.32 & -11.0 & -74.7 \\
\hline 335 & 14.07 & -11.0 & -75.0 \\
\hline 345 & 14.82 & -11.1 & -75.2 \\
\hline \multicolumn{4}{|c|}{$\left[\mathrm{N}_{1132-\mathrm{OH}}\right]\left[\mathrm{NTf}_{2}\right]+\mathrm{CO}_{2}$} \\
\hline 305 & 9.500 & -14.5 & -78.9 \\
\hline 315 & 10.29 & -14.5 & -78.9 \\
\hline 325 & 11.08 & -14.5 & -78.9 \\
\hline 335 & 11.86 & -14.5 & -78.9 \\
\hline 345 & 12.65 & -14.5 & -78.9 \\
\hline \multicolumn{4}{|c|}{$\left[\mathrm{N}_{1132-\mathrm{OH}}\right]\left[\mathrm{NTf}_{2}\right]+\mathrm{C}_{2} \mathrm{H}_{6}$} \\
\hline 305 & 12.93 & -11.0 & -78.3 \\
\hline 315 & 13.72 & -11.4 & -79.7 \\
\hline 325 & 14.52 & -11.8 & -81.0 \\
\hline 335 & 15.34 & -12.2 & -82.2 \\
\hline 345 & 16.17 & -12.6 & -83.3 \\
\hline
\end{tabular}

$\Delta_{\text {sol }} G^{\infty}$ is the Gibbs energy of solvation, $\Delta_{\text {sol }} H^{\infty}$ the enthalpy of solvation and $\Delta_{\text {sol }} S^{\infty}$ the entropy of solvation. The values are consistent with $p^{0}=0.1 \mathrm{MPa}$.
After a careful analysis of the present data and in light of the comparisons made, the present values are considered to be precise to within $\pm 1 \%$ with an estimated accuracy better than $\pm 5 \%$.

The effect of changing the cation of the IL is significant as can be observed in Fig. 4 where Henry's law constants obtained for carbon dioxide in this study and with imidazolium-, ammoniumor pyrrolidinium-based ILs are depicted. The results obtained in $\left[\mathrm{C}_{1} \mathrm{C}_{2} \mathrm{Im}\right]\left[\mathrm{NTf}_{2}\right]$ (two sets of data obtained with two different samples [4]) and $\left[\mathrm{C}_{1} \mathrm{C}_{4} \mathrm{Im}\right]\left[\mathrm{NTf}_{2}\right]$ confirm a slight increase of the solubility of carbon dioxide when increasing the chain length on the imidazolium ring of the cation. This phenomenon was already observed by other authors $[6,15,23]$. It can also be observed in this figure that the solubility of carbon dioxide in $\left[\mathrm{C}_{1} \mathrm{C}_{4} \mathrm{Im}\right]\left[\mathrm{NTf}_{2}\right]$ and in $\left[\mathrm{C}_{1} \mathrm{C}_{4}\right.$ pyrr] $\left.] \mathrm{NTf}_{2}\right]$ (ILs with two different cycles - one aromatic and one non-aromatic - but with the same alkyl chains on these cycles) is comparable. Concerning the ammonium cations, the addition of an alcohol function - comparison between $\left[\mathrm{N}_{4111}\right]\left[\mathrm{NTf}_{2}\right]$ and $\left[\mathrm{N}_{1132-\mathrm{OH}}\right]\left[\mathrm{NTf}_{2}\right]$ increases the Henry's law constant (solubility decreases). The higher solubility, measured by our group, for carbon dioxide in the IL with the pyrrolidinium cation, compared to the solubility in ammonium cation, was also observed by Anthony et
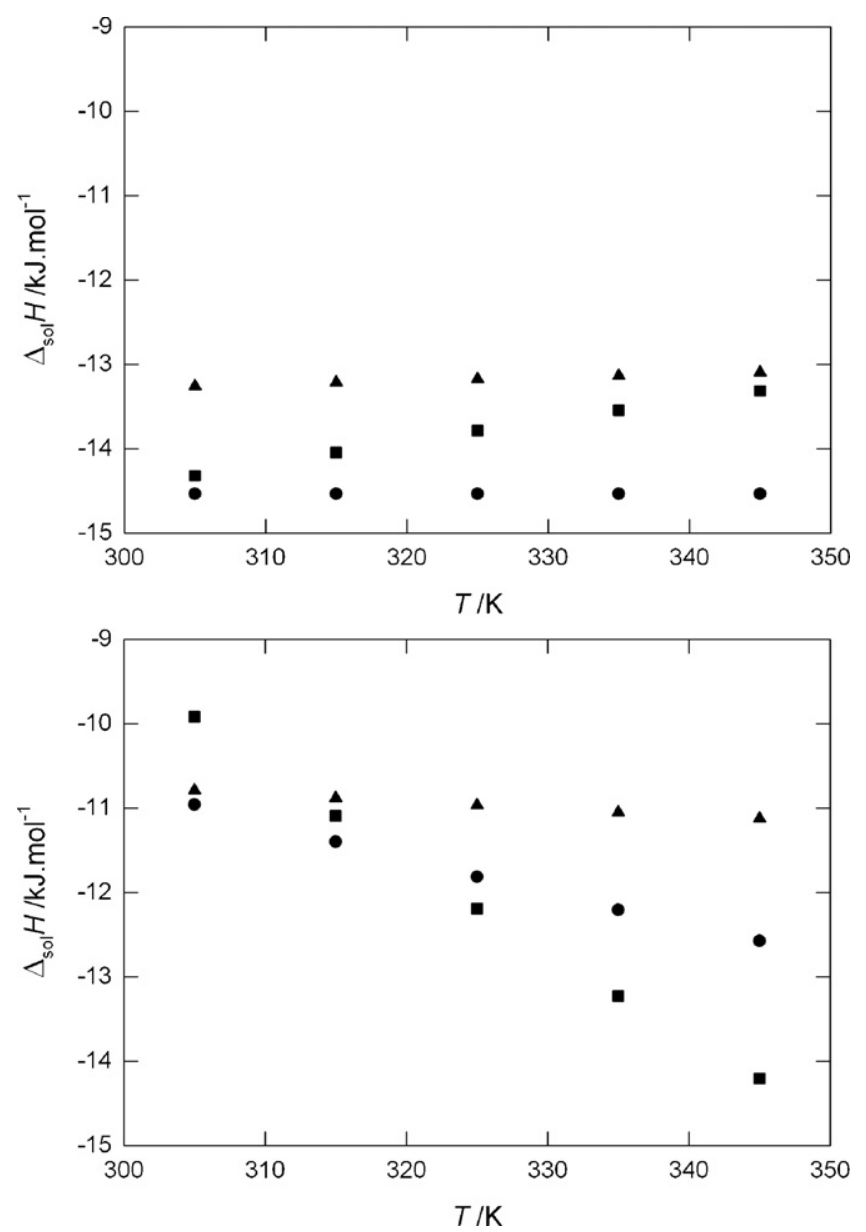

Fig. 5. Enthalpy of solvation of carbon dioxide (upper plot) and ethane (lower plot) in the three considered ILs as a function of temperature: $\left[\mathrm{C}_{1} \mathrm{C}_{2} \mathrm{Im}\right]\left[\mathrm{NTf}_{2}\right] ;(\boldsymbol{\Lambda})\left[\mathrm{C}_{1} \mathrm{C}_{4}\right.$ pyrr $]\left[\mathrm{NTf}_{2}\right]$; and $(\bullet)\left[\mathrm{N}_{1132-\mathrm{OH}}\right]\left[\mathrm{NTf}_{2}\right]$. 
al. [12]. Finally, the variations of the solubility caused by the change of the cation are slightly more important at higher temperatures. For example, carbon dioxide is $14 \%$ more soluble in pyrrolidinium-based IL than in ammonium-based IL at $303 \mathrm{~K}$, it is $21 \%$ more soluble at $344 \mathrm{~K}$.

The variation with temperature of the solubility, expressed in Henry's law constant, is directly related with the thermodynamic properties of solvation through Eqs. (4) and (5) and constitute a reasonable approximation, for the case of gaseous solutes at low pressure, of the thermodynamic properties of solution [35]. The values for the partial molar Gibbs energy, enthalpy and entropy of solvation are given for the six investigated systems in Table 3. Figs. 5 and 6 present the variation with temperature of the enthalpy and entropy of solvation for the considered systems, respectively.

The negative enthalpies of solvation calculated correspond to exothermic processes of solvation which means that the solvation is thus favoured at lower temperatures. More negative values were calculated for systems involving carbon dioxide. As can be observed in Fig. 6, all the systems investigated exhibit negative entropies of solvation. The properties of solvation of the two gases in $\left[\mathrm{C}_{1} \mathrm{C}_{4}\right.$ pyrr $]\left[\mathrm{NTf}_{2}\right]$ do not vary significantly with
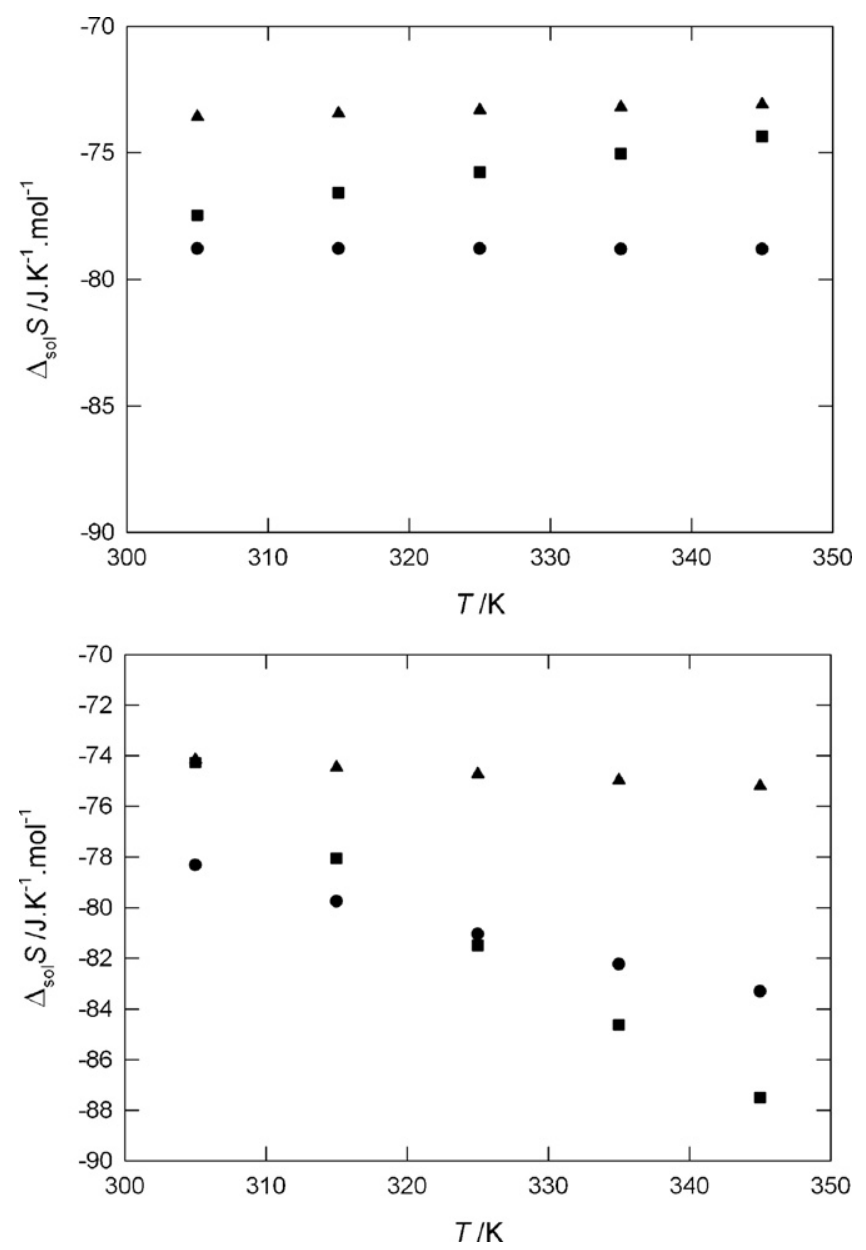

Fig. 6. Entropy of solvation of carbon dioxide (upper plot) and ethane (lower plot) in the three considered ILs as a function of temperature: $\left[\mathrm{C}_{1} \mathrm{C}_{2} \mathrm{Im}\right]\left[\mathrm{NTf}_{2}\right] ;(\boldsymbol{\Lambda})\left[\mathrm{C}_{1} \mathrm{C}_{4}\right.$ pyrr $]\left[\mathrm{NTf}_{2}\right]$; and $(\bullet)\left[\mathrm{N}_{1132-\mathrm{OH}}\right]\left[\mathrm{NTf}_{2}\right]$. temperature while important variations of these properties with temperature are depicted for both gases in $\left[\mathrm{C}_{1} \mathrm{C}_{2} \mathrm{Im}\right]\left[\mathrm{NTf}_{2}\right]$. In $\left[\mathrm{N}_{1132-\mathrm{OH}}\right]\left[\mathrm{NTf}_{2}\right]$, for the case of carbon dioxide, no significant variation of the properties is observed while they decrease for the case of ethane.

\section{Conclusions}

In this paper, the effect of changing the cation of the IL on the low-pressure solubility of two gaseous solutes, carbon dioxide and ethane, was investigated. The solubility of these gases was measured as a function of temperature using an accurate isochoric saturation method in $\left[\mathrm{C}_{1} \mathrm{C}_{4}\right.$ pyrr $]\left[\mathrm{NTf}_{2}\right],\left[\mathrm{C}_{1} \mathrm{C}_{2} \mathrm{Im}\right]\left[\mathrm{NTf}_{2}\right]$ and [ $\left.\mathrm{N}_{1132-\mathrm{OH}}\right]\left[\mathrm{NTf}_{2}\right]$. Carbon dioxide with mole fractions solubility between 1 and $3 \times 10^{-2}$, was found to be one order of magnitude more soluble than ethane. These data have been shown to be precise to within $\pm 1 \%$ and accurate to within $\pm 5 \%$. For all the systems, the solubility decreases with increasing temperature which corresponds to exothermic processes of solvation.

Although the effect of changing the cation on the solubility is less significant than the effect of changing the anion, it is still noticeable. Both gases appear as more soluble in the pyrrolidinium-based IL and less soluble in the ammonium-based IL studied, an observation already made by Anthony et al. [12]. Changing the cation has a similar effect on both gases.

Negative enthalpies (exothermic processes) and entropies of solvation were calculated for all the systems investigated. The properties of solvation of the two gases in $\left[\mathrm{C}_{1} \mathrm{C}_{4}\right.$ pyrr $]\left[\mathrm{NTf}_{2}\right]$ do not vary significantly with temperature while important variations are depicted for both gases in $\left[\mathrm{C}_{1} \mathrm{C}_{2} \mathrm{Im}\right]\left[\mathrm{NTf}_{2}\right]$.

\section{Acknowledgements}

MD thanks QUILL, the Royal Society and EPSRC for funding through the Portfolio Partnership.

\section{References}

[1] J. Jacquemin, M.F. Costa Gomes, P. Husson, V. Majer, J. Chem. Thermodyn. 38 (2006) 490-502.

[2] J. Jacquemin, M.F. Costa Gomes, P. Husson, V. Majer, Fluid Phase Equilib. 240 (2006) 87-95.

[3] P. Husson, J. Jacquemin, M.F. Costa Gomes, V. Mayer, Abstracts of the 21st European Symposium on Applied Thermodynamics ESAT 2005, Jurata, Poland, 2005

[4] J. Jacquemin, P. Husson, M.F. Costa Gomes, V. Majer, J. Sol. Chem., in press.

[5] P. Scovazzo, J. Poshusta, D. DuBois, C. Korval, R. Noble, J. Electrochem. Soc. 150 (5) (2003) D91-D98.

[6] R.E. Baltus, B.H. Culbertson, S. Dai, H. Luo, D.W. DePaoli, J. Phys. Chem. B 108 (2) (2004) 721-727.

[7] D. Camper, P. Scovazzo, C. Koval, R. Noble, Ind. Eng. Chem. Res. 43 (12) (2004) 3049-3054.

[8] D. Camper, C. Becker, C. Koval, R. Noble, Ind. Eng. Chem. Res. 45 (2006) 445-450.

[9] D. Morgan, L. Ferguson, P. Scovazzo, Ind. Eng. Chem. Res. 44 (2005) 4815-4823.

[10] D. Camper, C. Becker, C. Koval, R. Noble, Ind. Eng. Chem. Res. 44 (2005) $1928-1933$ 
[11] J.L. Anthony, E.J. Maginn, J.F. Brennecke, J. Phys. Chem. B 106 (29) (2002) 7315-7320.

[12] J.L. Anthony, J.L. Anderson, E.J. Maginn, J.F. Brennecke, J. Phys. Chem. B 109 (2005) 6366-6374.

[13] A.P.S. Kamps, D. Turm, J. Xia, G. Maurer, J. Chem. Eng. Data 48 (2003) 746-749.

[14] C. Cadena, J.L. Anthony, J.K. Shah, T.I. Morrow, J.F. Brennecke, E.J. Maginn, J. Am. Chem. Soc. 126 (2004) 5300-5308.

[15] S.N.V.K. Aki, B.R. Mellin, E.M. Saurer, J.F. Brennecke, J. Phys. Chem. B 108 (2004) 20355-20365.

[16] S. Zhang, X. Yuan, Y. Chen, X. Zhang, J. Chem. Eng. Data 50 (2005) $1582-1585$.

[17] Y.S. Kim, W.Y. Choi, J.H. Jang, K.P. Yoo, C.S. Lee, Fluid Phase Equilib. 228-229 (2005) 439-445.

[18] M.C. Kroon, A. Shariati, M. Costantini, J. van Spronsen, G.J. Witkamp, R.A. Sheldon, C.J. Peters, J. Chem. Eng. Data 50 (2005) 173-176.

[19] A. Shariati, K. Gutkowski, C.J. Peters, AIChE J. 51 (5) (2005) 1532-1540.

[20] M.B. Shiflett, A. Yokozeki, Ind. Eng. Chem. Res. 44 (2005) 4453-4464.

[21] M.B. Shiflett, A. Yokozeki, AIChE J. 52 (3) (2006) 1205-1219.

[22] B.C. Lee, S. Outcalt, J. Chem. Eng. Data 51 (2006) 892-897.

[23] Y. Chen, S. Zhang, X. Yuan, Y. Zhang, X. Zhang, W. Dai, R. Mori, Thermochim. Acta 441 (2006) 42-44.

[24] L.A. Blanchard, Z. Gu, J.F. Brennecke, J. Phys. Chem. B 105 (2001) 2437-2444.

[25] P. Bonhôte, A.P. Dias, N. Papageorgiou, K. Kalyanasundaram, M. Gratzel, Inorg. Chem. 35 (1996) 1168-1178.
[26] C. Villagrán, M. Deetlefs, W.R. Pitner, C. Hardacre, Anal. Chem. 76 (1996) 2118-2123.

[27] IUPAC Commission on Atomic Weights and Isotopic Abundances. Atomic weights of the elements 1985, Pure Appl. Chem. 58 (1986) 16771692.

[28] J.H. Dymond, E.B. Smith, The Virial Coefficients of Pure Gases and Mixtures, Clarendon Press, Oxford, 1980.

[29] J. Jacquemin, P. Husson, A. Padua, V. Majer, Green Chem. 8 (2006) $172-180$.

[30] A. Noda, K. Hayamizu, M. Watanabe, J. Phys. Chem. B 105 (2001) $4603-4610$

[31] M. Krummen, P. Wasserscheid, J. Gmehling, J. Chem. Eng. Data 47 (2002) 1411-1417.

[32] C.P. Fredlake, J.M. Crosthwaite, D.G. Hert, S.N.V.K. Aki, J.F. Brennecke, J. Chem. Eng. Data 49 (2004) 954-964.

[33] H. Tokuda, K. Hayamizu, K. Ishii, M.A.B.H. Susan, S. Tsuzuki, M. Watanabe, J. Phys. Chem. B 109 (2005) 6103-6110.

[34] J. Deschamps, M.F. Costa Gomes, A.A.H. Padua, ChemPhysChem 7 (2004) 1049-1052.

[35] M.F. Costa Gomes, A.A.H. Padua, Pure Appl. Chem. 77 (3) (2005) 653-665.

[36] J.M. Prausnitz, R.N. Lichtenthaler, E.G. de Azevedo, Molecular Thermodynamics of Fluid-Phase Equilibria, Prentice Hall Inc., Englewood Cliffs, New Jersey, 1986.

[37] M.F. Costa Gomes, A.A.H. Padua, J. Phys. Chem. B 107 (2003) 14020-14024. 